\title{
An Evaluation of Relationship between Foreign Direct Investment and Economic Growth in Vietnam
}

\author{
PHẠM THỊ HOÀNG ANH \\ Banking Academy - anhpham1076_bham@yahoo.com \\ LÊE HÀ THU \\ Banking Academy - lehathu2011@gmail.com
}

ARTICLE INFO

Article history:

Received:

Aug. 1, 2013

Received in revised form

Accepted:

Sep. 11, 2013

March 31, 2014

\section{ABSTRACT}

Foreign direct investment (FDI) is an essential source of capital in the gross investment conducive to national economic growth, including the case of Vietnam. Since the 1987 Foreign Investment Law, the country has attracted a large amount of foreign capital, which makes a significant contribution to economic development. This research employs a VAR model to analyze the relationship between FDI and Vietnam's economic growth. The results suggest that FDI has a positive impact on the latter and vice versa. The research also finds that FDI stimulates export and improves the quality of human

Keywords:

FDI, economic growth, resources and technology - important prerequisites for the economic growth. 


\section{INTRODUCTION}

Foreign Direct Investment (FDI) plays an important role in economic growth of a nation, especially developing ones. Vietnam is not an exception since FDI flows tend to increase over the years and positively impact economic development. The introduction of the 1987 Foreign Investment Law, as a milestone, starts the country's integration process, allowing FDI flows to be perceived as an additional source to fill the shortage of domestic investment. FDI inflows into Vietnam have since then increased significantly in terms of both quality and quantity.

Some viewpoints suggest that FDI exerts many positive effects on Vietnam's economy, such as job creation, income increase, export boosts, and improvement in the balance of payments, whereas others maintain that excessive FDI will lead to 'bubbles' in certain sectors like real estate and stock market in Vietnam in recent times, damaging the national economy. In addition, the question of whether or not the economic growth is one of factors attracting FDI inflows into Vietnam is also controversial.

Theoretically, economic growth brings profits to investors and hence promotes FDI. Is this observation true for Vietnam's case? The two-way relationship, as can be seen, between economic growth and FDI is not only a subject of scholars' interest, but it also draws assiduous attention of policy makers, especially in such developing countries as Vietnam.

There has recently been a range of studies on FDI in Vietnam. For example, Nguyễn \& Haughton (2002) and Parker et al. (2005) indicate that the US- Vietnam BTA helps attract huge FDI flows into Vietnam. Meyer \& Nguyen (2005) demonstrate legal factors with their significant impacts on decisions on investment in Vietnam by foreign partners. Also, Nguyen (2006), employing GMM, confirms a positive relationship between the two variables in Vietnam; and Tran (2009) suggests that FDI improves the national infrastructure and vice versa.

These views highlight a good aspect but the methods and contents of these researches fail to give a comprehensive assessment of the relationship, which leaves open this research to examine: (i) the mutual impact between economic growth and FDI in Vietnam through a vector autoregressive model (VAR), and (ii) comprehensive solutions to improve and enhance the impact. 


\section{FDI INFLOWS IN VIETNAM}

Vietnam has achieved high growth rates of GDP in the past decades and therefore attracted a significant volume of FDI.

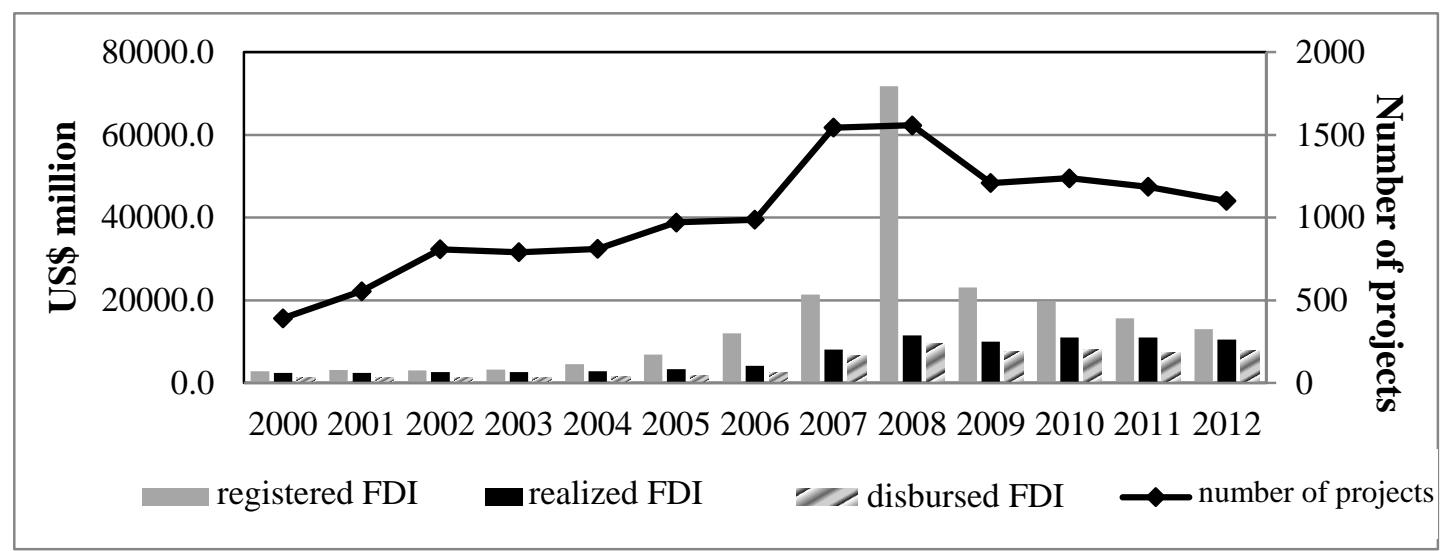

Figure 1: FDI Inflows in Vietnam in the Years 2000 - 2012

Source: SBV, GSO, and MPI

Figure 1 clearly illustrates two trends of changes in FDI inflows. The growth period was from 2000 to 2008 although the amount of FDI into Vietnam decreased slightly due to unfavorable investment climate and bad effects of the 1997-99 Asian financial crises. In the years 2003-2008, the volume of realized FDI in Vietnam rose from US $\$ 2,650$ to 11,500 million and disbursed one from US\$1,450 million to $\$ 9,579$ million.

In the years 2005-2007, Vietnam achieved high growth rates of GDP, over $8 \%$, and in 2007 it became a WTO member, which also made investors feel secured about its economic growth. However, the inflows gradually dropped between 2008 and 2012. The number of projects and registered FDI dramatically fell, whereas realized and disbursed FDI decreased more slowly, from US\$9,579 and US\$10,500 million to US\$7,783 and 10,460 million respectively. Obviously, the global financial crisis in 2008-2009 or European public debt crisis did not affect much the FDI inflows into Vietnam. This implies FDI's long-term safety and its essential role in economic growth of many countries, including Vietnam.

The prevalent mode of FDI is wholly foreign-owned enterprise since it ensures full control over business and the most favorable division of profit for foreign investors. Additionally, when MNEs have certain knowledge of Vietnam market, the advantages of joint ventures as the main mode of FDI contracts in Vietnam in the period 1988-1996 
will fade away. Improvement in the Vietnamese FDI law that allows all modes of FDI projects makes the rise in number of wholly foreign-owned enterprises inevitable. The other two modes of FDI - business cooperation contracts and joint stock enterprises make only minor contributions. With the development of Vietnam's stock market since its accession to the WTO, the mode of joint-stock enterprises is increasingly popular.

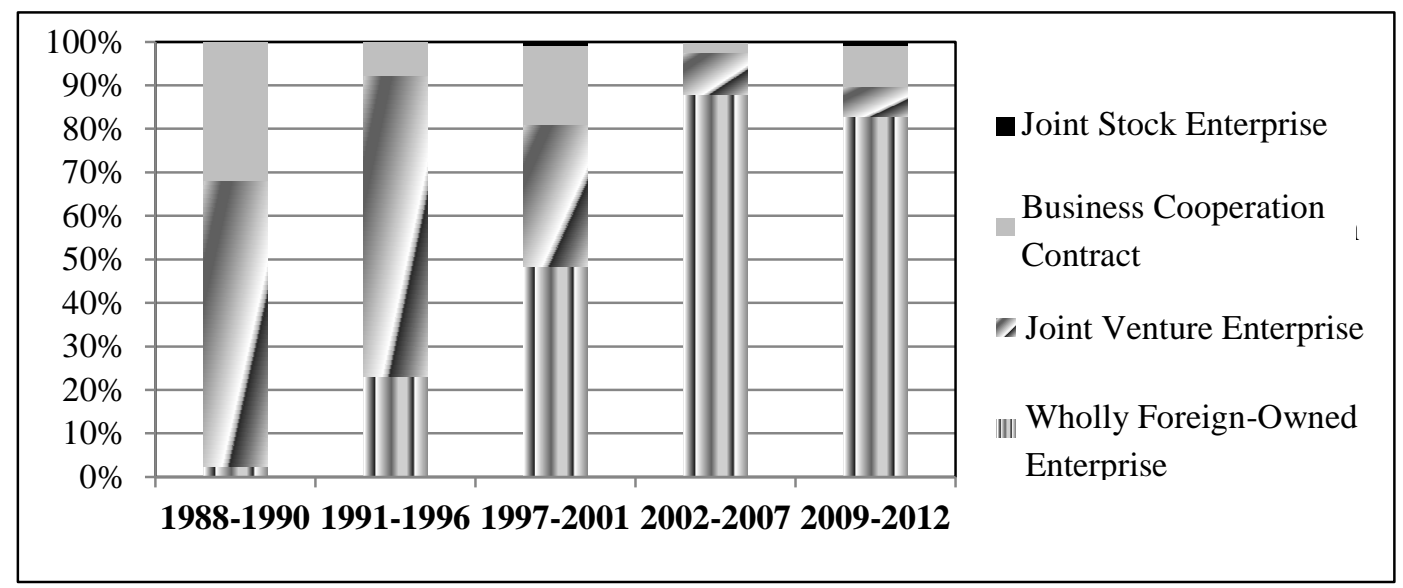

Figure 2: Modes of FDI in Vietnam

Source: MPI and authors' calculations

The most attractive sectors for FDI inflows are manufacturing and service, in which real estate attracts many foreign investors' interests. The situation created a "bubble" in the real estate market in the past few years, producing negative effects on Vietnam's economic growth.

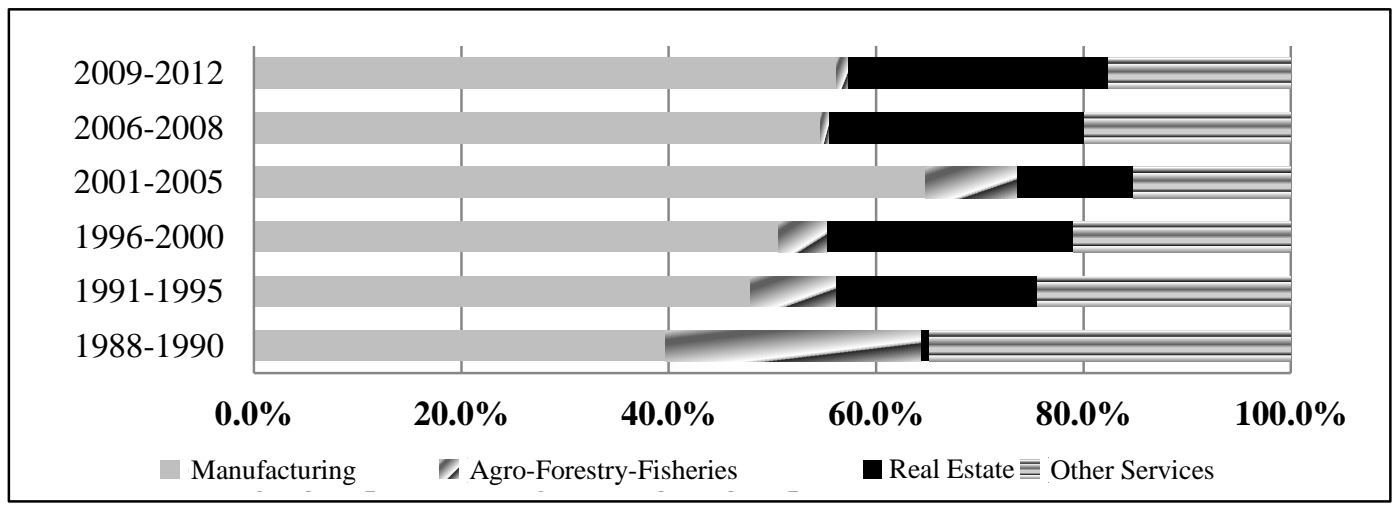

Figure 3: FDI by Sector

Source: MPI and authors' calculations 
Table 1: Top 10 Foreign Investors in Vietnam up to 2012

\begin{tabular}{lccc}
\hline \multicolumn{1}{c}{ Country/Territory } & Project & Registered FDI (US\$ mil.) & Rank \\
\hline Japan & 1,827 & $29,145.57$ & 1 \\
Taiwan & 2,268 & $26,428.45$ & 2 \\
South Korea & 3,186 & $24,794.54$ & 3 \\
Singapore & 1,099 & $24,670.59$ & 4 \\
British Virgin Islands & 522 & $16,031.96$ & 5 \\
Hong Kong & 700 & $11,995.71$ & 6 \\
Malaysia & 433 & $11,367.79$ & 7 \\
U.S.A & 639 & $10,467.82$ & 8 \\
Cayman Islands & 54 & $7,505.99$ & 9 \\
Thailand & 298 & $6,006.44$ & 10 \\
\hline
\end{tabular}

Source: MPI

Table 2: Registered FDI by Regions and in Oil Business up to 2012

\begin{tabular}{|c|c|c|c|}
\hline Region & Project & Registered FDI (US\$ mil.) & Rank \\
\hline Hồng Delta & 3,952 & $48,143.71$ & 2 \\
\hline Northeast & 432 & $7,725.86$ & 6 \\
\hline Northwest & 44 & 438.04 & 9 \\
\hline North of Central Vietnam & 210 & $19,180.70$ & 4 \\
\hline $\begin{array}{l}\text { South of Coastal Central } \\
\text { Vietnam }\end{array}$ & 525 & $20,635.18$ & 3 \\
\hline Western Highlands & 139 & 821.53 & 8 \\
\hline Eastern South & 8,380 & $10,3101.26$ & 1 \\
\hline Mekong Delta & 759 & $10,951.37$ & 5 \\
\hline Oil & 48 & $2,653.69$ & 7 \\
\hline
\end{tabular}

Source: MPI 
Leading investors in Vietnam include countries with long-term diplomatic relations with Vietnam like Japan, China, South Korea and some ASEAN countries such as Singapore and Malaysia. Additionally, provinces with highest FDI volumes are usually in alluvial plains with favorable geographical positions, large population and highly qualified human resources such as Eastern South and Hồng Delta (Table 2).

\section{RECIPROCAL IMPACT BETWEEN FDI AND ECONOMIC GROWTH IN VIETNAM}

\section{a. Model Description:}

To evaluate the impact between FDI and Vietnam's economic growth, the VAR model introduced by Shan (2002) is used. Factors and values selected for the model include: (i) GDP - Gross Domestic Product (at constant 1994 price) (VND billion); (ii) FDI - disbursed FDI (US\$ million); (iii) CAPITAL - gross investment (VND billion); (iv) EX - goods export earnings (US\$ million); (v) LABOR - working population aged 15 and above (thousand people); (vi) EDU - number of college students (thousand people); (vii) TECH - ratio of Internet users (\%).

The data series were collected quarterly from the GSO, SBV, and VNNIC under the Ministry of Information - Communication from Quarter 1/2004 to Quarter 3/2012 and were then seasonally adjusted (except for FDI data, to satisfy a stationary test - Unit Root Test) by Census X12 method, represented in natural logarithm. There are a total of 35 observations, and the summary of time series is shown in Table 3.

Table 3: Statistical Summary of Variables

\begin{tabular}{lccccccc}
\hline & GDP & FDI & CAPITAL & EX & LABOR & EDU & TECH \\
\hline Mean & $120,295.5$ & $1,467.800$ & 148.6229 & $14,849.71$ & 48.12417 & $1,814.949$ & 0.226649 \\
Median & $115,706.0$ & $1,723.000$ & 138.0000 & $13,717.00$ & 47.16030 & $1,719.500$ & 0.236100 \\
Maximum & $178,188.0$ & $2,864.000$ & 276.9000 & $30,217.00$ & 55.00000 & $2,478.000$ & 0.354900 \\
Minimum & $71,080.00$ & 247.0000 & 58.45000 & $5,520.000$ & 43.00890 & $1,319.800$ & 0.076900 \\
Std. Dev. & $26,727.80$ & 799.5958 & 66.86573 & $6,828.145$ & 3.327926 & 364.4153 & 0.087665 \\
Observations & 35 & 35 & 35 & 35 & 35 & 35 & 35 \\
\hline
\end{tabular}

Before including variables in the model, the ADF unit root test of the data series is performed. Stationary test results suggest that all variables are stationary at the first difference. According to LR test, the appropriate lag length of Model 1 is one quarter. 
The stability of the model, after VAR estimation, should be considered to determine whether the model is appropriate or not. The test shows that the roots of characteristic polynomial are all smaller than 1 and within the unit circle. In addition, the results of Portmanteau test based on $\mathrm{Q}$ statistics suggest that with different lags, $p$-values of $\mathrm{Q}$ statistics are all greater than $5 \%$, i.e. hypothesis $\mathrm{H}_{0}-$ no residual autocorrelation exists - is accepted and the model is considered to satisfy this condition (no residual autocorrelations). The White's test for heteroskedasticity is performed to check the variance homogeneity and the test result shows that hypothesis $\mathrm{H}_{0}$ is accepted or the model ensures variance heterogeneity[1]. These results imply that the VAR model employed to evaluate the impact between FDI and Vietnam's economic growth is appropriate and stable.

\section{b. Analysis of FDI Impact on Macro Variables:}

Table 4: Variance Decomposition

\begin{tabular}{cccccccc}
\hline Period & DGDP & DCAPITAL & DEX & DLABOR & DEDU & DTECH & DFDI \\
\hline 1 & 7.726025 & 0.000000 & 0.000000 & 3.998771 & 0.000000 & 0.283230 & 87.16454 \\
2 & 8.149404 & 0.591100 & 0.857457 & 3.767603 & 0.000888 & 5.479267 & 84.29872 \\
3 & 8.498843 & 1.696841 & 1.856862 & 3.432814 & 0.144744 & 5.961336 & 82.39116 \\
4 & 8.910691 & 3.165529 & 2.486634 & 3.315384 & 0.309440 & 6.244780 & 80.16776 \\
5 & 9.195931 & 4.440231 & 2.783759 & 3.359924 & 0.411738 & 6.351886 & 78.39173 \\
6 & 9.362152 & 5.308888 & 2.896991 & 3.469061 & 0.466241 & 6.390293 & 77.23597 \\
7 & 9.441188 & 5.803644 & 2.931397 & 3.575505 & 0.491545 & 6.400024 & 76.59398 \\
8 & 9.471869 & 6.044577 & 2.938384 & 3.652302 & 0.501781 & 6.400893 & 76.28484 \\
9 & 9.480852 & 6.144340 & 2.938529 & 3.698203 & 0.505262 & 6.400241 & 76.15648 \\
10 & 9.482184 & 6.178079 & 2.938188 & 3.721771 & 0.506177 & 6.399968 & 76.11191 \\
\hline
\end{tabular}


Figure 4: Response of Variables to FDI
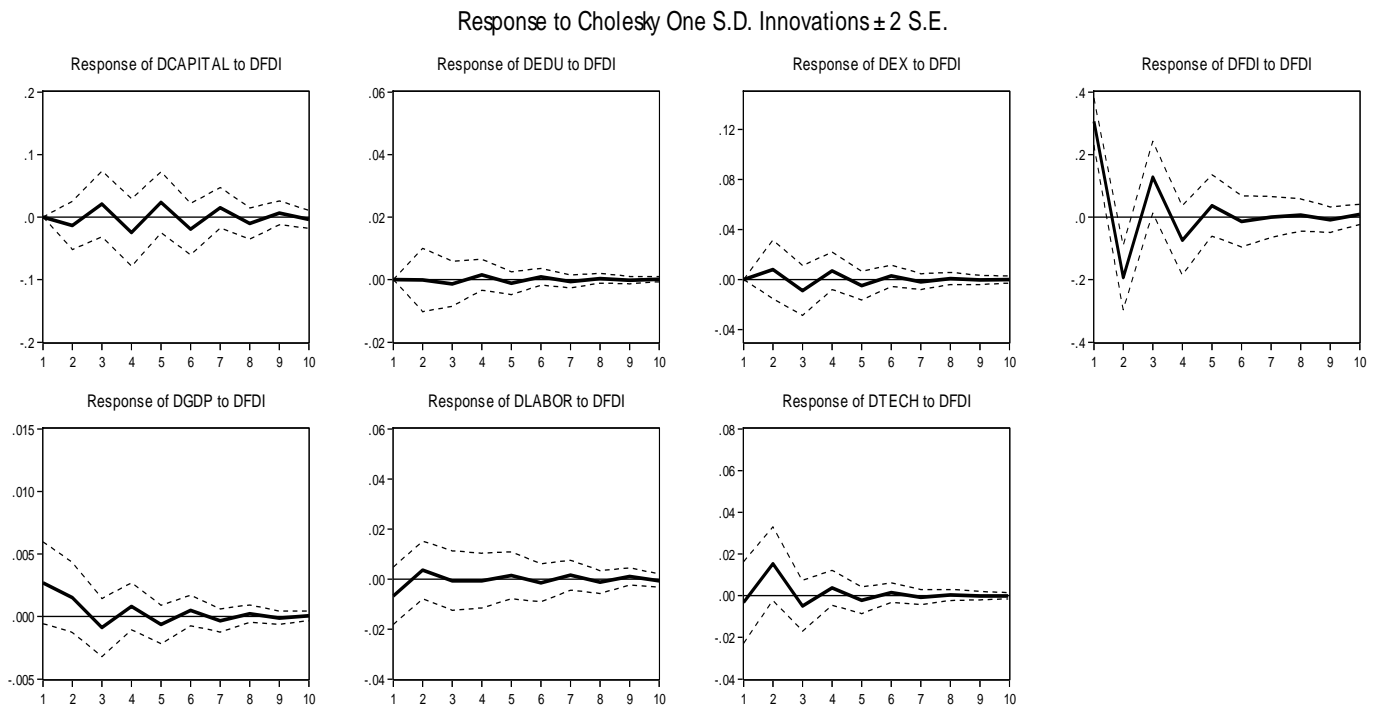

(1) FDI Impact on Vietnam's Economic Growth

The results from the model demonstrate that FDI has a positive and direct impact on Vietnam's economic growth during surveyed periods, which is compliant with the theory of the relationship between these two as well as empirical evidence found by Nguyen \& Haughton (2002), Parker et al. (2005) and Nguyen (2006).

Figure 5: Vietnam's GDP by Sectors in 2005-2011[2]

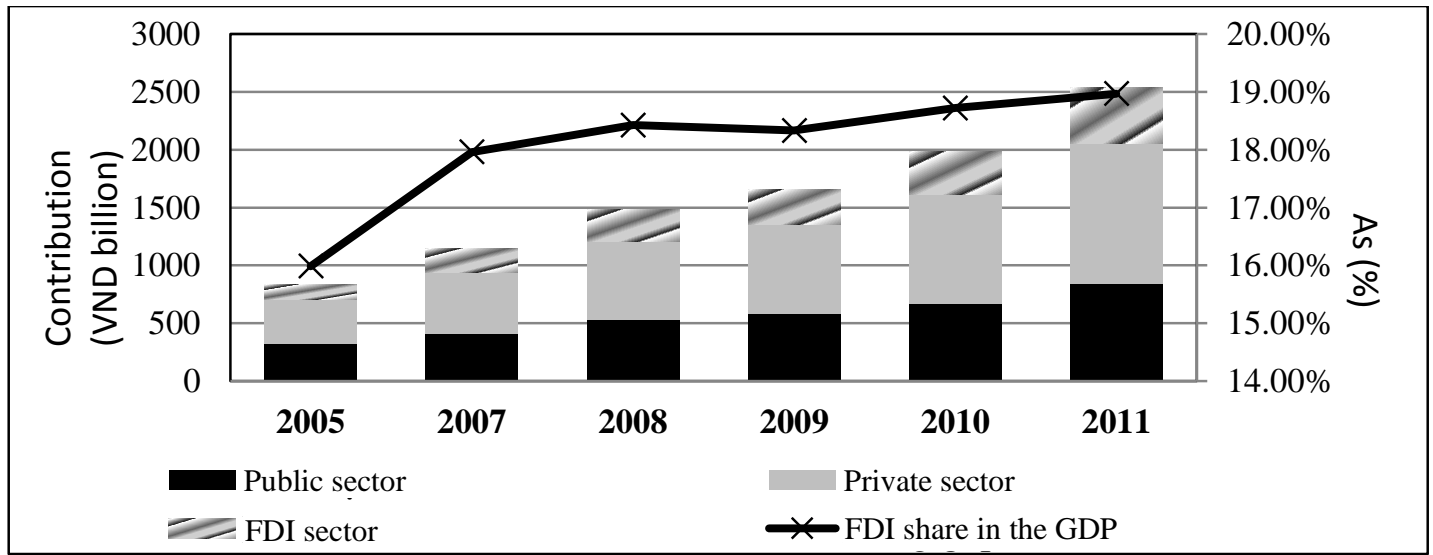

Source: GSO 
Figure 5 illustrates that both value and share of FDI in Vietnam's GDP increase over the years. The FDI share rises significantly between 2005 and 2008, from 15.99\% to $18.43 \%$ with an average increase of 0.813 percentage point per year thanks to the Vietnam's high economic growth rates and accession to the WTO in this period. Yet, performance of all sectors, due to the 2008 global financial crisis, declines in 2009, resulting in a fall in FDI contribution to the GDP. The next phase 2010-2011, along with Vietnam's economic recovery, witnesses a moderate rise in the FDI share in the growth rate because Vietnam faces unfavorable upheavals at macroeconomic level such as inflation and bad debt.

(2) FDI Impact on Gross Investment

FDI is shown to have a positive impact on CAPITAL with a lag length of two or three quarters. In fact, it does not only increase the gross investment but also stimulates more contributions from domestic sectors. This is similar to findings by Mitra (2007) and Takagi \& Pham (2011).

Figure 6: Gross Investment by Sectors in 2000-2012 (VND billion \& \%)

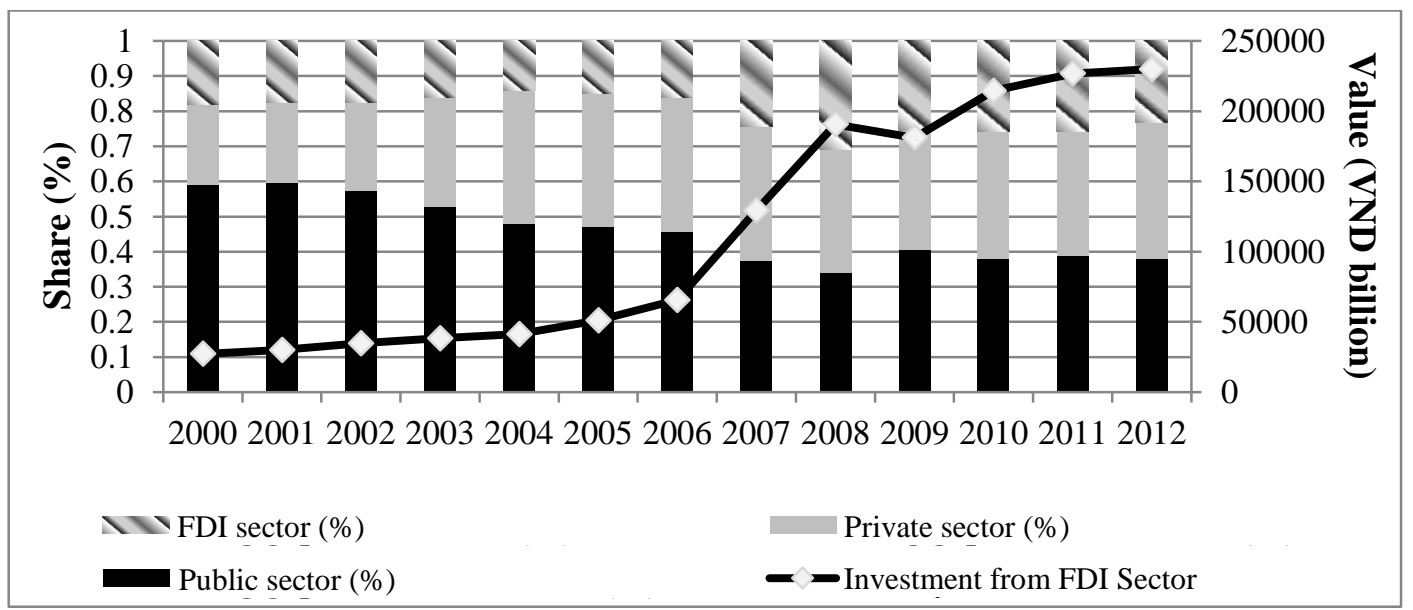

Source: GSO and authors' calculations

Contribution from the foreign sector rises by over 10 times, from VND22, 000 in 1995 to 230,000 billion in 2012. This stimulates increases in other two sectors, especially the private one, and shows that the FDI inflow not only helps increase the gross investment but also gives some orientation to flows of investment in Vietnam. From this aspect, an increase of FDI in any industry will boost domestic investment; therefore, the 
FDI, as an additional source of capital, directly encourage domestic investment, thereby increasing the gross investment.

(3) FDI Impact on Export

The FDI sector in the past years made a significant contribution to Vietnam's export. The graph of respond function shows that FDI has an immediate positive impact on export earnings, and reaches its peak after two quarters. In reality, the share of FDI in export earnings between 1995 and 2012 keeps increasing, from 27.03\% to $63.01 \%$ (or $\$ 1.473$ billion to $\$ 72.2$ billion).

However, value of import by the FDI sector is also high, accounting for over $50 \%$ of Vietnam's import turnover and tends to rise faster than its export one due to the high demand of this sector for high-cost imported machinery. In addition, FDI enterprises have to import large quantities of raw materials because: (i) domestic supply does not meet their requirements; and (ii) FDI enterprises in Vietnam, as parts of international production chains, have to import materials from those in the same chain. This makes added value generated by the FDI sector is not as high as expected and partly reduces its positive impact on Vietnam's export turnover.

\section{Figure 7: FDI Import and Export Turnover and Its Shares in Vietnam's Export} and Import in 2000-2012

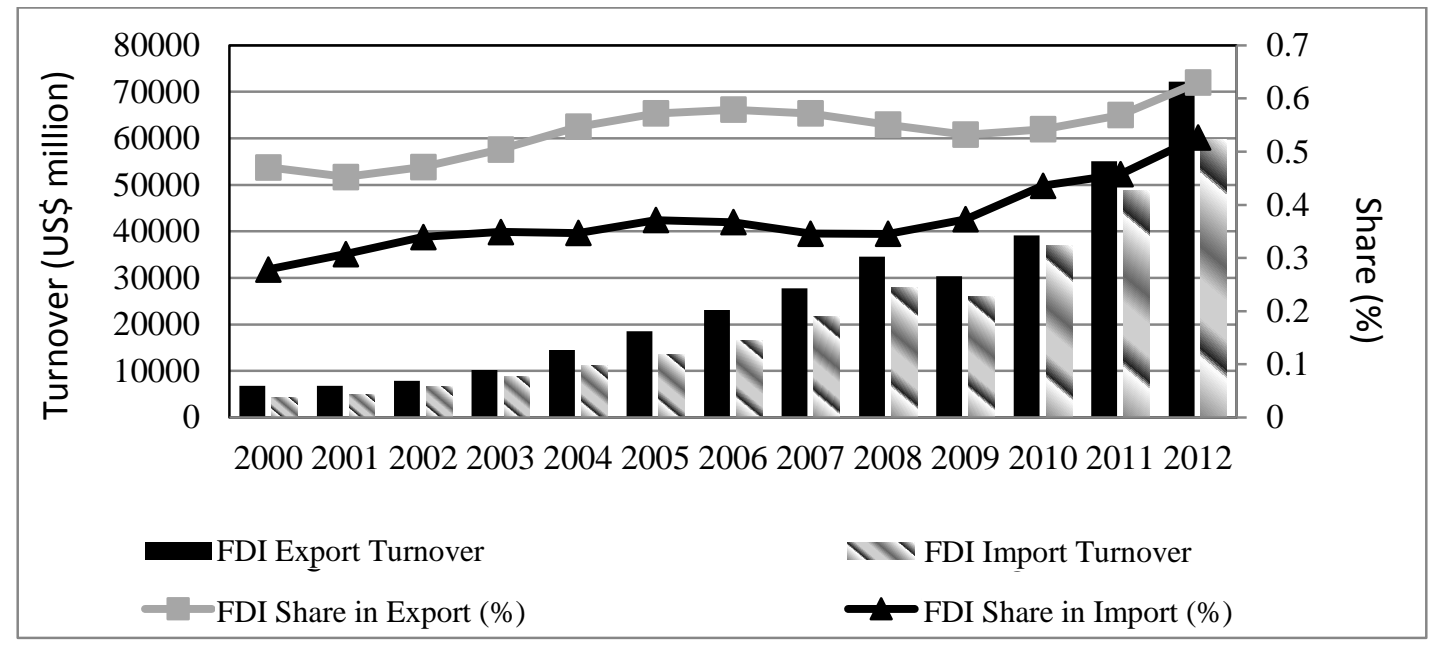

Source: GSO

(4) FDI Impact on Labor Force 
The graph of response function illustrates that FDI exerts a positive impact on LABOR after two quarters. Initially, response of LABOR to FDI is negative because the building of foreign-invested factories reduces farming land, which negatively affects employment and labor force. After the building, however, FDI demand for labor boosts the growth of Vietnam's labor force, causing significant improvement in labor income (Figure 8).

Figure 8: Labor Force and Income in FDI Sector in 2000-2012[4]

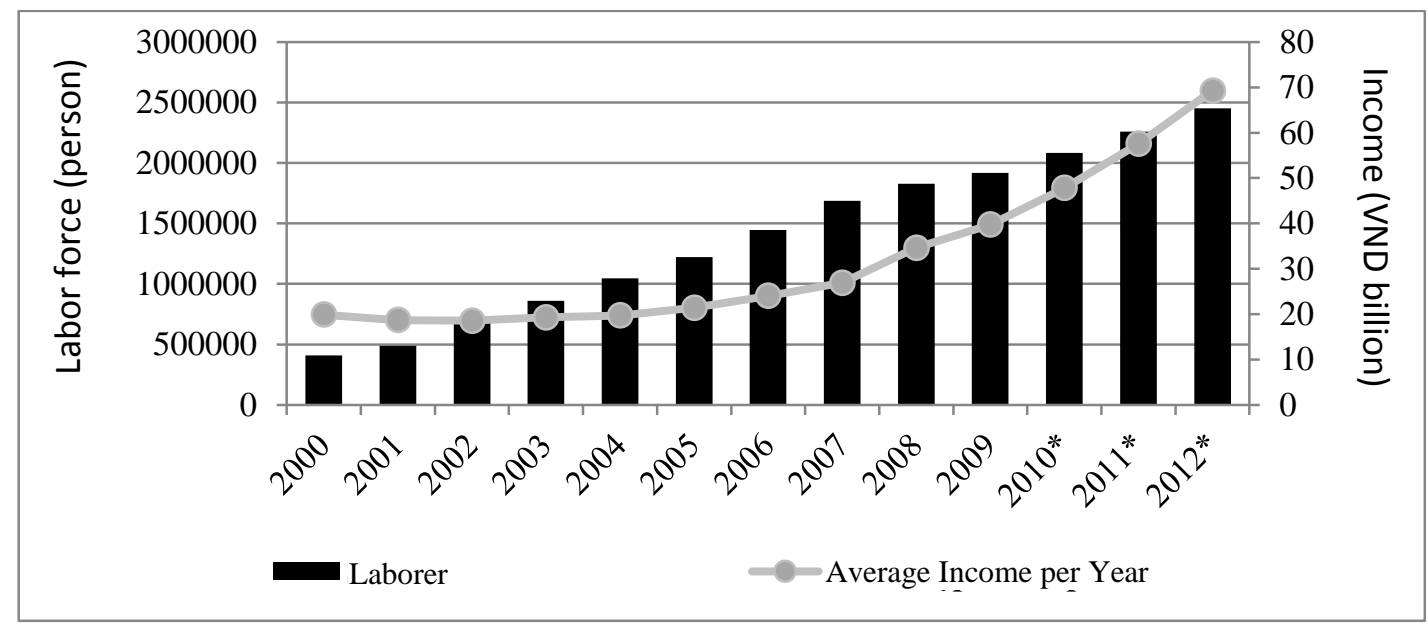

Source: GSO

(5) FDI Impact on the Quality of Human Resources

The curve of EDU response to FDI fluctuates around 0 and largely lies on the horizontal axis, suggesting that FDI has a positive impact on the quality of Vietnam's human resources although the impact is not strong. This is because most FDI enterprises in Vietnam undertake labor-intensive processes such as assembling. Even Vietnam branches of leading high-tech companies like Samsung and Intel only produce component parts used as inputs for their larger factories in other countries. Thus, the FDI demand for highly skilled labor in Vietnam is not great, mitigating the positive impact of FDI on the quality of the local human resources. Moreover, many projects by Chinese partners, one of major investors in Vietnam, instead of recruiting local labors, often employ native Chinese workers, which significantly affects Vietnam's labor market.

(6) FDI Impact on Technological Level 
The graph of the response function shows that FDI has its greatest impact on TECH after two quarters. Statistics reveal that internet users increased from 2,334,634 persons in 2003 to $31,304,211$ in 2012[4], and this promising fact could be explained by the following reasons:

First, the FDI sector produces spillover effects upon Vietnam's economic growth and subsequently upon its technological level as well. In this process, high economic growth helps improve income and living standards of local residents quantitatively and qualitatively, which allows them to get access to modern technologies.

Second, the application of modern technology in production chains of FDI enterprises, especially those operating in high-tech fields, as in information technology, electronics and telecommunications and automation, also promotes technological diffusion effects and improve Vietnam's technological level. Despite the fact that many FDI enterprises in Vietnam only undertake assembling work, the spillover effects upon technological level of workers in particular and local residents in general can hardly be denied.

\section{c. Impact of Economic Growth on FDI:}

Figure 9: FDI Response to Variables

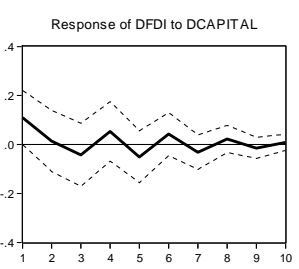

Response of DFDI to DGDP

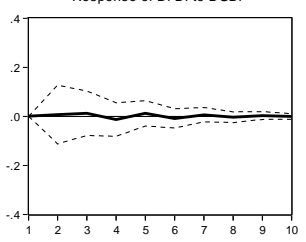

Response to Cholesky One S.D. Innovations \pm 2 S.E.

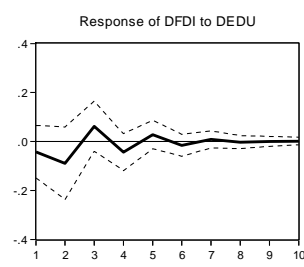

Response of DFDI to DLABOR

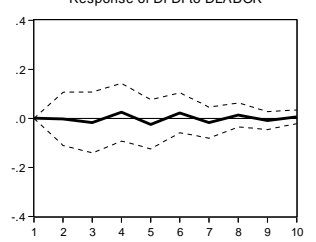

Response of DFDI to DEX

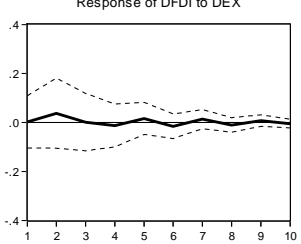

Response of DFDI to DTECH

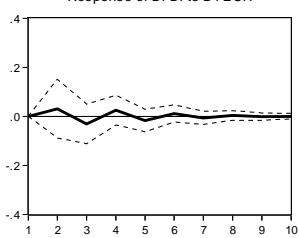

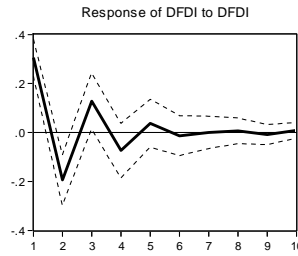


Table 5: Decomposition of Factors Affecting FDI in VAR Model

\begin{tabular}{ccccccccc}
\hline Period & S.E. & DCAPITAL & DEDU & DEX & DFDI & DGDP & DLABOR & DTECH \\
\hline 1 & 0.327536 & 11.15681 & 1.674783 & 0.003863 & 87.16454 & 0.000000 & 0.000000 & 0.000000 \\
2 & 0.394199 & 7.826026 & 6.317226 & 0.921129 & 84.29872 & 0.027321 & 0.003980 & 0.605598 \\
3 & 0.422932 & 7.810952 & 7.642661 & 0.801275 & 82.39116 & 0.105798 & 0.176124 & 1.072031 \\
4 & 0.436655 & 8.813647 & 8.177235 & 0.834357 & 80.16776 & 0.198701 & 0.479299 & 1.328996 \\
5 & 0.443539 & 9.845761 & 8.323460 & 0.947029 & 78.39173 & 0.263663 & 0.783880 & 1.444477 \\
6 & 0.447110 & 10.57590 & 8.322908 & 1.062273 & 77.23597 & 0.299447 & 1.018117 & 1.485383 \\
7 & 0.448980 & 10.99322 & 8.286609 & 1.146857 & 76.59398 & 0.315835 & 1.169026 & 1.494477 \\
8 & 0.449949 & 11.19351 & 8.255391 & 1.197631 & 76.28484 & 0.321959 & 1.253266 & 1.493399 \\
9 & 0.450440 & 11.27357 & 8.237411 & 1.223591 & 76.15648 & 0.323647 & 1.294445 & 1.490855 \\
10 & 0.450681 & 11.29847 & 8.229591 & 1.234960 & 76.11191 & 0.323842 & 1.311960 & 1.489260 \\
\hline
\end{tabular}

First, FDI response to itself, among others, is the strongest. In other words, an increase/decrease in FDI value in a period explains $70-80 \%$ of changes in FDI in the next period. This implies that FDI inflows into Vietnam are determined by the size of investment made in the previous period by foreign investors, i.e. by characteristics of investors, such as their sentimentality and taste for risk, etc. Hence, FDI inflows are unstable and easily affected by such factors as market prices or investment trends. Any change in domestic as well as international markets does strongly affect the inflows, which cause adverse impacts on Vietnam's economic growth.

The second important variable is the gross investment that can explain $11 \%$ of changes in FDI inflows into Vietnam. In a favorable investment climate, reflected by an increase in domestic and foreign investment, there will also be an increase in FDI inflows.

About $8 \%$ of changes in FDI are governed by labor education (EDU), which positively affects FDI with a lag of around 3 quarters as demonstrated in the graph. With a steady increase in FDI inflows into Vietnam's high-tech industries, labor education becomes increasingly important to the flows of FDI to Vietnam. 
The remaining variables, including GDP, LABOR, EX, and TECH, have no explanatory significance to FDI flows into Vietnam, approximately $1 \%$. In spite of a relatively well-developed technology market in Vietnam, only consumer goods are available, whereas input markets are not active enough. Vietnam has to import even consumer goods because they cannot produce them, which reveals that the level of technology is not improved enough to affect remarkably the FDI.

Additionally, Vietnam offers an abundant labor force because of its young population structure. However, with poor skill levels, this labor force has a low impact on FDI. Another factor is export; FDI has a significant impact on the total export turnover of Vietnam. Yet, as analyzed above, the exports mainly to other subsidiaries for next production stages do not help expand export market for Vietnam, and the impact of this variable on FDI is also limited.

Last, economic growth does positively impact FDI into Vietnam although it determines only $1 \%$ of changes in the FDI flow. Theoretically, economic growth can produce positive effects on the FDI because it increases expected profits for investors. Still, Vietnam's situations reveal that an increase in growth rate does lead to a rise in disbursed FDI even though there are limitations as follows:

In 2006, the growth rate decreases, and yet disbursed FDI proceeded to increase. Firstly, such a decrease is not significant, i.e. from $8.44 \%$ in 2005 to $8.22 \%$ in 2006, not reflecting a decline in Vietnam's economy. Secondly, the Vietnam's growth rate, in spite of its slight decrease, is still at a high level compared with other countries, making it a promising destination for foreign investment.

In 2008, the growth rate drastically decreased but the disbursed FDI, as long-term investments, still increased. Vietnam's economy may suffer negative impacts from the global economic crisis, but they are not very serious due to its "shallow integration" as a new WTO member.

The year 2012 witnesses another decrease in Vietnam's growth rate as a result of the tight monetary policy in the previous years. This, however, does not mean a fall in production and high growth rate of export makes disbursed FDI increase in 2012. 
Figure 10: GDP Growth and Disbursed FDI in VN in 2000-2012

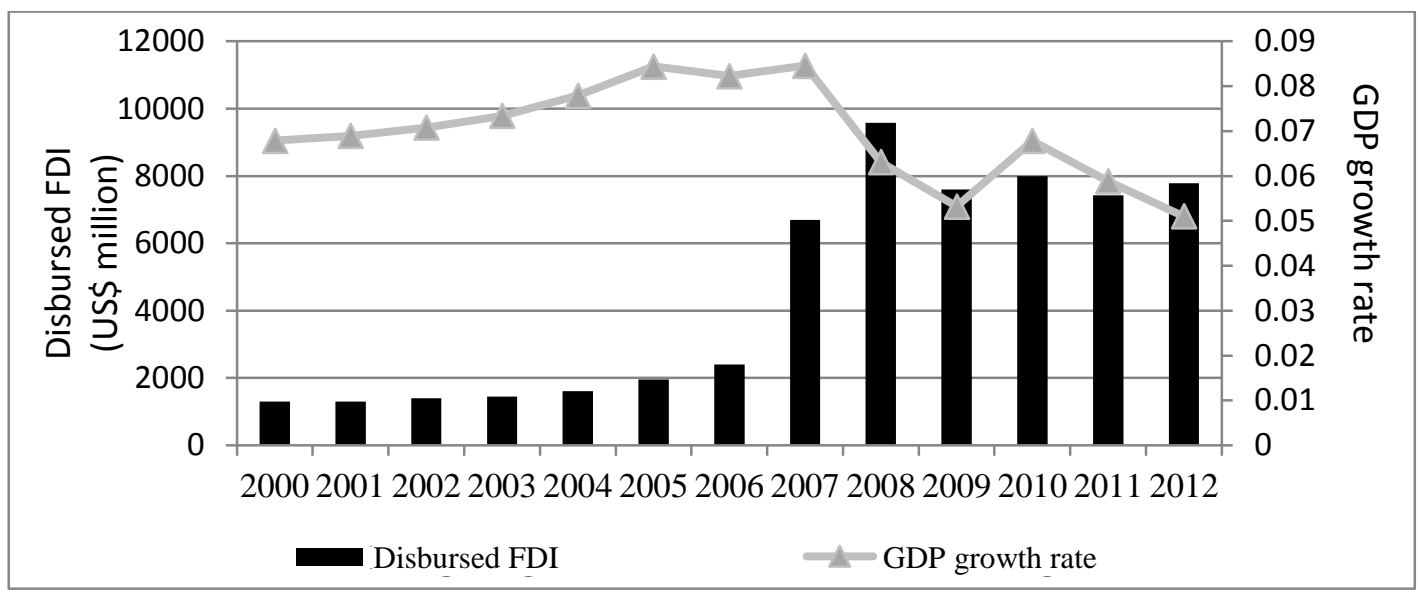

Source: GSO \& SBV

The VAR model shows that FDI and economic growth have a reciprocal relationship in which the FDI helps boost economic growth and conversely, the latter is one the factors that encourage foreign investors to transfer their businesses to Vietnam. Nevertheless, there are a few negative effects produced by FDI, including the following:

Firstly, FDI affects Vietnam's economic growth extensively and fails to change it intensively. As with a current growth model, which mainly depends on labor and capital, FDI has been playing a crucial role in national economic growth. FDI impact on development of local technologies, however, is still weak and therefore could not stimulate intensive economic growth.

Secondly, although FDI makes significant contributions to export and improvements in the trade balance, import value by this sector, at times, increases even faster than its export value. This implies that FDI enterprises fail to make use of local resources to make exports, that is, fail to produce positive effects on domestic production and longterm economic growth.

Lastly, the foreign sector has affected the environment in Vietnam to a certain extent, particularly the negative impacts caused by such foreign-invested companies as Vedan and Miwon, which damage Vietnam's sustainable economic development. Hence, environmental issues have been taken into consideration and treated as a key standard for approving FDI projects by authorities. 


\section{CONCLUSION AND POLICY RECOMMENDATION}

\section{a. FDI Impact on Economic Growth:}

FDI exerts a positive impact on all of the variables in the model, particularly on economic growth (GDP), gross investment (CAPITAL) and technology (TECH), but the positive impact is not much apparent on education (EDU), labor force (LABOR) and export (EX). Therefore, to improve FDI impact on economic growth, as can be seen, it is necessary to enhance its impact on such factors as gross investment, technology, human resource, labor force and export.

Firstly, the current macroeconomic instability should be addressed, especially high inflation, bad debt, and large inventory causing a huge backlog of asset value in enterprises and adversely affecting economic growth.

Secondly, there should be continuing improvement in investment climate to enhance the contribution of FDI in particular and investment from other sectors in general to the gross investment.

Thirdly, to make the best use of spillover effect of FDI projects, the government should encourage foreign investors to invest in high-tech sectors, such as information technology and telecommunications and take specific measures to enhance local production of high-tech goods to improve the domestic technological level and increase the share of FDI in the GDP. In addition, FDI needs to be oriented to the production of Vietnam staple exports, such as farm products, garments, footwear, and mining, etc., which not only raises productivity in these industries due to high technological levels of the FDI sector but also promote its export and supports exportation from local enterprises.

Fourthly, investment in and/or promotion of education and training with clear orientation toward high-tech industries and sectors requiring application of advanced managerial and business skills, as in financial - banking, hotel management and tourism, etc. can help attract more FDI and meet the demand for well trained labor by this sector, thereby promoting on-the-job training by local companies as well as diffusion effects of FDI manpower quality.

Lastly, to improve the trade balance of FDI sector as well as of the entire economy, there is a need to direct economic resources toward supporting industries that supply raw materials used for making exports. The point is to support input providers, reduce the 
production cost for producers of exports, cut import value, and improve balances of trade and of payments, thereby supporting economic growth.

\section{b. Impact of the Other Variables on FDI:}

Among the factors affecting the flow of FDI into VN, FDI value of the previous period is the most decisive one, which implies that special attention should be paid to market stabilization, improvement in legal infrastructure, and simplification of investment procedures to encourage foreign investors to seek for business opportunities in Vietnam and stimulate more FDI inflows into VN.

Furthermore, gross investment, economic growth, export, labor force, human resource quality and technological level have less profound impacts on the FDI. Particularly, to enhance the impact of economic growth, there is the need to develop policies on the use of revenue from economic growth into investments in infrastructure, human resource and national technology to subsequently stimulate the FDI into VN. The promotion of export by directing FDI flows toward export-oriented industries and increasing the gross investment, besides the aforementioned issues, should be well noticed.

In sum, through model tests and arguments, the research has proved mutual impacts between the FDI and Vietnam economic growth. This allows several policy recommendations to be made in an effort to improve the management of FDI flows and reciprocal impacts between the FDI and economic growth

\section{Note:}

[1] Due to limited space of an article, results of test for stability of the model cannot be presented here but can be provided as requested.

[2] In this section, statistics supplied by the GSO are insufficient, so analysis can only be performed up to 2011 .

[3] Estimation of the data for the period before 2010 is based on trends of upheavals in the past.

[4] Data are from VNNIC.

\section{References}

Alfano, L., A. Chanda, S.K. Ozcan \& S. Sayek (2003), "FDI Spillovers, Financial Markets, and Economic Development", IMF Working Paper No. 03/186. 
Carp, L. (2012), "Analysis of the Relationship between FDI and Economic Growth - Literature Review Study”, The USV Annals of Economics and Public Administration, Vol.12 (1), pp.154160.

Johnson, A. (2006), “The Effect of FDI Inflows on Host Country Economic Growth", The Royal Institute of Technology, Working Paper Series in Economics and Institutions of Innovation No.58.

Meyer, K.E. \& H.V. Nguyen (2005), "Foreign Investment Strategies and Sub-national Institutions in Emerging Markets: Evidence from Vietnam”, Journal of Management Studies, Vol.42 (1), pp.6393.

Mirza, H. \& A. Giroud (2004), "Regional Integration and Benefits from Foreign Direct Investment in ASEAN Economies: The case of Viet Nam", Asian Development Review, Vol.21 (1), pp.66-98.

Mitra, P. (2007). "Has Public Investment Crowded In or Crowded Out Private Investment in Vietnam”, IMF Selected Issues SM/07/341, pp.46-62.

Nguyen, N.A. \& T. Nguyen (2007), "Foreign Direct Investment in Vietnam: An Overview and Analysis the Determinants of Spatial Distribution across Provinces”, MPRA Paper No. 1921.

Nguyen, N.B. \& J. Haughton (2002), "Trade Liberalisation and Foreign Direct Investment in Vietnam”, ASEAN Economic Bulletin, Vol.19 (3), pp.302-318.

Nguyen, P.L. (2006), "FDI and Its Linkage to Economic Growth in Vietnam: A Provincial Level Analysis", Centre for Regulation and Market Analysis, University of South Australia, working paper.

Nguyen, P.L. \& S. Anwar (2010), "Foreign Direct Investment and Economic Growth in Vietnam", Asia Pacific Business Review, Vol.16 (1-2), pp.183-202.

Nguyễn Thị Tuệ Anh, Vũ Xuân Nguyệt Hồng, Trần Toàn Thắng \& Nguyễn Mạnh Hải (2006), “Tác động của đầu tư trực tiếp nước ngoài tới tăng trưởng kinh tế Việt Nam”, Project SIDA 2001 - 2010 sponsored by CIEM.

Parker, S., V.Q. Phan \& N.A. Nguyen (2005), "Has the U.S.-Vietnam Bilateral Trade Agreement Led to Higher FDI into Vietnam?” International Journal of Applied Economics, Vol.2(2), pp.199-223.

Ray, S. (2012), "Impact of Foreign Direct Investment on Economic Growth in India: A Co integration Analysis”, AITM, Vol.2 (1), pp.187-201.

Shan, J. (2002), "A VAR Approach to the Economics of FDI in China”, Applied Economics, Vol.34 (7), pp.885-893.

Takagi, S. \& T. H.A. Pham (2011), "Dynamic Interaction between Foreign and Domestic Investment in Vietnam", Vietnam Economic Management Review, Vol.6 (2).

Toulaboe, D., R. Terry \& T. Johansen (2009), "Foreign Direct Investment and Economic Growth in Developing Countries”, Southwestern Economic Review, Vol.26 (1), pp.155-170.

Tran, Q.T. (2009), "Sudden Surge in FDI and Infrastructure Bottlenecks: The Case in Vietnam", ASEAN Economic Bulletin, Vol.26 (1), pp.58-76. 